\title{
Occurrence of Microcerella halli (Engel) (Diptera, Sarcophagidae) in snake carrion in southeastern Brazil
}

\author{
Thiago de C. Moretti ${ }^{1}$, Silmara M. Allegretti², Cátia A. Mello-Patiu ${ }^{3}$, Alexandre M. Tognolo², \\ Odair B. Ribeiro ${ }^{2} \&$ Daniel R. Solis ${ }^{4}$
}

\begin{abstract}
'Departamento de Parasitologia, Instituto de Biociências, Universidade Estadual Paulista "Júlio de Mesquita Filho", 18618-000, Botucatu-SP, Brazil. tcmoretti@yahoo.com.br

${ }^{2}$ Departamento de Biologia Animal, Instituto de Biologia, Universidade Estadual de Campinas, 13083-970, Campinas-SP, Brazil. sallegre@unicamp.br; tognolo.alexandre@ig.com.br; bemribeiro@yahoo.com.br

${ }^{3}$ Departamento de Entomologia, Museu Nacional, Universidade Federal do Rio de Janeiro, 20942-040, Rio de Janeiro-RJ, Brazil. camello@acd.ufrj.br

${ }^{4}$ Centro de Estudos de Insetos Sociais, Instituto de Biociências, Universidade Estadual Paulista "Júlio de Mesquita Filho", 13506-900, Rio Claro-

SP, Brazil. entomo75@yahoo.com
\end{abstract}

\begin{abstract}
Occurrence of Microcerella halli (Engel) (Diptera, Sarcophagidae) in snake carrion in southeastern Brazil. The occurrence of 27 second-instar larvae of the flesh fly Microcerella halli (Engel, 1931) (Diptera, Sarcophagidae) in a carcass of a snake usually called as Urutu, Bothrops alternatus (Duméril, Bibron \& Duméril, 1854) (Serpentes, Viperidae, Crotalinae) is reported. The snake was kept in captivity in a snake farm in Morungaba, São Paulo state, Brazil. Descriptions of reptile carcass colonization by insects and general biological data of this flesh fly are scarce and this necrophagic behavior is described for the first time in literature.
\end{abstract}

KEYWORDS. Flesh flies; fly colonization; forensic entomology; reptile carcass.

RESUMO. Ocorrência de Microcerella halli (Engel) (Diptera, Sarcophagidae) em uma Carcaça de Cobra no Sudeste Brasileiro. A ocorrência de 27 larvas de segundo estádio do sarcofagídeo Microcerella halli (Engel, 1931) (Diptera, Sarcophagidae) em uma carcaça de urutu Bothrops alternatus (Duméril, Bibron \& Duméril, 1854) (Serpentes, Viperidae, Crotalinae) é relatada. A cobra era mantida em cativeiro em um serpentário no município de Morungaba, estado de São Paulo, Brasil. Descrições de colonização de carcaças de répteis por insetos e dados gerais da biologia deste sarcofagídeo são escassos, e este comportamento necrófago é descrito pela primeira vez na literatura.

PALAVRAS-CHAVE. carcaça de réptil; colonização por moscas; entomologia forense; sarcofagídeos.

Bothrops alternatus (Duméril, Bibron \& Duméril, 1854) (Serpentes, Viperidae, Crotalinae) is known in Brazil as Urutu, Cruzeiro, Cruzeira, Jararaca de Agosto, Jararaca rabo-de-porco, Coatiara, Cotiara, Boicoatiara and Boicotiara (Campbell \& Lamar 1989). This species has broad dispersion in South America (Barrio \& Miranda 1966) occurring in Brazilian forests in Minas Gerais and possibly southern Goiás, countryside of São Paulo, Paraná, Santa Catarina, Rio Grande do Sul and Mato Grosso. It can be also found in Uruguay, south Paraguay and central and north regions of Argentina (Campbell \& Lamar 1989). Regarding its habitat, B. alternatus is encountered in fens, swamps and other wet sites, being very common in sugarcane plantations.

The genus Microcerella Macquart (Diptera, Sarcophagidae) is restricted to the New World and contains 74 species, six of which have been recorded from the Nearctic region (Pape 1996, Mariluis 2006). Species of Microcerella in the Neotropical region usually inhabit high altitude sites, with the highest species richness occurring in the southern temperate zones. The genus has preference to feed on decomposing animal matter, especially dead invertebrates. The saprophytic habit is also suggested by the morphology of the first instar larva, which exhibits conspicuous mandibles and well formed clypeal arch (Lopes 1982).

Microcerella halli (Engel, 1931) is common in Bolivia, Argentina and Brazil (states of Minas Gerais, São Paulo, Rio de Janeiro and Ceará). In the states of São Paulo and Rio de Janeiro, $M$. halli is considered synanthropic.

A given area, localized either in tropical or temperate zones, contains a considerable amount of rodents of several sizes, snakes, frogs and birds, in addition to the young of large animals, their abortions and afterbirths (Blackith \& Blackith 1990), all of them being considered small carcasses. The colonization of such resources by invertebrates is often neglected although it may provide information of forensic importance.

In fact, the fate of the vast number of small carcasses (including reptiles) in some habitats, as well as the parameters 
that control this process, are not objective of important studies (Moretti et al. 2008).

Most of the studies dealing with colonization of carcasses utilize mammal carrion (pigs, dogs, rabbits and rodents), basically because the data obtained can be extrapolate to human forensic investigations (Schoenly et al. 2006). Moreover, these types of carcasses are more currently available at universities, bioteries and research centers. According to Frye (1991), myiasis is common in reptiles, such as in the American chameleon, Anolis carolinensis (Blake 1955); in the Grand Canyon rattlesnake, Crotalus viridis abyssus (Garrigues 1964); in the teiid lizard, Ameiva chrysolaema (Smith et al. 1994); in the South American rattlesnake, Crotalus durissus terrificus (Silva et al. 1999) and in the green anole lizard, Anolis carolinensis (Irschick et al. 2006).

However, there are few studies on the colonization of reptile carcasses by insects, such as in Cornaby (1974) and Kneidel (1984), who utilized, respectively, carrion of lizards (Iguana iguana and Ctenosaura similis) and carrion of snakes (Carphophis amoenus, Diadophus punctatus, Opheodrys aestivus and Nerodis sipedon). Blackith \& Blackith (1988), dealing specifically with colonization of a snake carrion, described two new species of sarcophagid (Sarcophaga claviger and Sarcophaga disneyi). None of these studies mentioned the occurrence of $M$. halli in the reptile carcasses.

The present study focuses on the occurrence of $M$. halli in a $B$. alternatus carcass, which was previously kept in captivity, aiming both to contribute to the understanding of insect colonization in reptile carrion and to gather information on the biology of this flesh fly. The specimen of $B$. alternatus object of the present study was approximately 20 months of age, weighed 385 grams and was $110 \mathrm{~cm}$ in total length. It was kept individually in a plastic container $(40 \times 30 \times 22 \mathrm{~cm})$ at $30^{\circ} \mathrm{C}$ in a snake farm in the municipality of Morungaba (22 $52^{\prime} 48^{\prime \prime} S$, $46^{\circ} 47^{\prime} 30^{\prime \prime} W$ ), São Paulo state, Brazil. After its death, we examined the reptile to check it for the presence of internal parasites.

Upon post-mortem internal examination, we came across 27 second-instar larvae of a sarcophagid fly firmly attached to the external tegument, digestive and respiratory systems (lungs outer surface) of the reptile. The snake had died approximately four days prior to this examination, according to the biologist responsible for the snake farm. The larvae were collected and deposited in a plastic vial containing raw ground beef and vermiculite (for pupation), covered with organza and transferred to a climatic chamber kept at $25 \pm 1^{\circ} \mathrm{C}$, $75 \%$ of relative humidity with a 12 -hour photoperiod until the emergence of the adults. After 21 days, the adult males $(n=10)$ were identified as Microcerella halli (male specimens are more currently used for identification purposes in the family Sarcophagidae). Only one flesh fly female specimen has emerged and remained unidentified. The other 16 larvae died prior to pupation.

The adult male observed characters were: ninth sternite reduced, palpi genitalium very peculiar in shape, showing a ventral apophysis, theca small, paraphallus well sclerotized, a very large membranous region occupying the ventral part of penis, apical plate bifid, well sclerotized, lateral plates very large with an acute and recurrent terminal apophysis, ventralia situated internally, partially covered by lateral plates, styli elongated, apically dentate, the bases united, median process also apically dendate, long and curved, conspicuous sclerotized plates connecting the glans with apical plate and ventralia (Lopes 1973).

Microcerella halli prefers to feed on decomposed animal organic matter, as pointed out by Lopes (1982). Hence, it is possible to infer that the colonization occurred after the death of the snake, which was already exhaling a typical decomposing odor when it was found. Consequently, a case of myiasis must be excluded.

This flesh fly species has been cited in some forensic studies, such as in Moura (2004) and Moura et al. (2005), in which the larviposition occurred in rats and mice - mammal carcasses. In the present study the larviposition took place in reptile carrion. Therefore, it is possible to deduct that $M$. halli does not show any specificity in relation to the taxon of the colonized carcass, which is in accordance to Kneidel (1984), who asserted that various species of flies reared from nonmammal small carcasses are opportunistic scavengers of a great variety of organic sources.

Although the knowledge of the relative abundance of different carcass taxons in natural environments is still scarce, it is a fact that small animal carcasses are more unpredictable sources compared to large animal carcasses, since the former ones are more susceptible to variations in the physical environment and to the consumption by vertebrates or large invertebrates (e.g. Coleoptera). Further investigations on the fate of non-mammal carcasses in natural environments, as well on the biology of $M$. halli are strongly suggested, especially in the current context of the growing importance of forensic entomology in the Neotropical region (Mavárez-Cardozo et al. 2005).

\section{REFERENCES}

Barrio, A. \& M. E. Miranda. 1966. Las diferentes poblaciones de Bothrops alternata Duméril \& Bibron (Ophidia, Crotalidae) de la Argentina, consideradas desde el punto de vista morfológico y antigénico. Memórias do Instituto Butantan 33: 887-892.

Blackith, R. E. \& G. R. Blackith. 1988. Sarcophagini from northern Sulawesi (Indonesia), including four new species (Diptera: Sarcophagidae). Japanese Journal of Sanitary Zoology 39: 301-311.

Blackith, R. E. \& G. R. Blackith. 1990. Insect infestation of small corpses. Journal of Natural History 24: 699-709.

Blake, D. H. 1955. Note on the rearing of Anolisimyia blakeae, a sarcophagid fly from the American chameleon, Anolis carolinensis Voight (Diptera, Sarcophagidae). Proceedings of the Entomological Society of Washington 57: 187-188.

Campbell, J. A. \& W. W. Lamar. 1989. The venomous reptiles of Latin America. Cornell University Press, New York, USA.

Cornaby, B. W. 1974. Carrion Reduction by Animals in Contrasting Tropical Habitats. Biotropica 6: 51-63.

Frye, F. L. 1991. Biomedical and surgical aspects of captive reptile husbandry. Krieger Publishing Co., Florida, USA. 
Garrigues, R. M. 1964. A Cuterebra (Diptera: Cuterebridae) infestation in the Grand Canyon Rattlesnake, Crotalus viridis abyssus, with a list of those recorded from other hosts. Transactions of the Kansas Academy of Sciences 67: 689-692.

Irschick, D. J.; G. Gentry; A. Herrel \& B. Vanhooydonck. 2006. Effects of sarcophagid fly infestations on green anole lizards (Anolis carolinensis): an analysis across seasons and age/sex classes. Journal of Herpetology 40: 107-112.

Kneidel, K. A. 1984. Influence of carcass taxon and size on species composition of carrion-breeding Diptera. American Midland Naturalist 111: 57-63.

Lopes, H. S. 1973. Two new genera of Neotropical Sarcophagidae (Diptera). Revista Brasileira de Biologia 33: 193-199.

Lopes, H. S. 1982. The genera of Microcerellini (Diptera: Sarcophagidae). Revista Brasileira de Biologia 42: 359-369.

Mariluis, J. C. 2006. Description of a new species of Microcerella (Diptera: Sarcophagidae) from Argentinean Patagonia. Zootaxa 1124: 47-53.

Mavárez-Cardozo, M. G.; A. I. Espina de Fereira; F. A. Barrios-Ferrer \& J. L. Fereira-Paz. 2005. La Entomología Forense y el Neotrópico. Cuadernos de Medicina Forense 11: 23-33.

Moretti, T. C.; O. B. Ribeiro; P. J. Thyssen \& D. R. Solis. 2008. Insects on decomposing carcasses of small rodents in a secondary forest in
Southeastern Brazil. European Journal of Entomology 105: 691696.

Moura, M. O. 2004. Variação espacial como mecanismo promotor da coexistência em comunidades de insetos necrófagos. Revista Brasileira de Zoologia 21: 409-419.

Moura, M. O.; C. J. B. de Carvalho \& E. L. A. Monteiro-Filho. 2005. Estrutura de comunidades necrófagas: efeito da partilha de recursos na diversidade. Revista Brasileira de Zoologia 22: 1134-1140.

Pape, T. 1996. A catalogue of the Sarcophagidae of the World (Insecta: Diptera). Memoirs of Entomology International 8: 1-558.

Schoenly, K.; N. H. Haskell; D. K. Mills; C. Bieme-Ndi; K. Larsen \& Y. Lee. 2006. Recreating death's acre in the school yard: using pig carcasses as model corpses to teach concepts of forensic entomology and ecological succession. American Biology Teacher 68: $402-410$.

Silva, R. J.; A. P. Prado; R. R. Rodrigues; C. A. M. Lopes \& W. A. C. Godoy. 1999. Megaselia scalaris (Diptera: Phoridae) causing myiasis in Crotalus durissus terrificus (Serpentes: Viperidae) in Brazil. Journal of Medical Entomology 36: 630.

Smith, D. D.; P. T. Schell.; R. Powel \& J. S. Parmerlee.1994. Pharyngeal myiasis by Sarcophagi (sic) larvae (Diptera) in Ameiva chrysolaema (Sauria: Teiidae) from the Dominican Republic. Caribbean Journal of Science 30: 148-149.

Received 07/09/2008; accepted 29/04/2009 